\title{
Knowledge Improvement of Preventing Sexually Transmitted Disease to Students of SMP Negeri 1 Talawaan Kecamatan Dimembe, North Minahasa
}

\author{
Chreisye K. F. Mandagi ${ }^{1, *}$, Sekplin A. S. Sekeon ${ }^{1}$ \\ ${ }^{1}$ School of Public Health, Sam Ratulangi University, Indonesia \\ *Corresponding author. Email: mandagichreisye@unsrat.ac.id
}

\begin{abstract}
Lack of information and knowledge from the youth students about sexually transmitted disease (STD) can lead to increment to the numbers of the sexually transmitted disease among the youth. SMP Negeri I Talawaan is one of the schools located in North Minahasa. Presenting the education or information related to sexual issues si still considered toboo and trigger pros-cons among the society in the village of Talawaan, Kecamatan dimembe. Thus, the information about the education and the risk of sexually transmitted disease is necessary to improve he knowledge of the students about STD so that the students can prevent STD in early stage. This is a quasi-experiment with One Group Pretest Posstest approach that have been held in August 2019. The sample used was a total of 78 students at SMP Negeri I Talawaan $7^{\text {th }}$ grade and $8^{\text {th }}$ grade. Data collecting on this research by using questionnaire. Knowledge level about the STD before the socialization which categorized as good knowledge category is 21 respondents amounted to (26.92\%), fair knowledge category is 49 respondents $(62.82 \%)$, and less knowledge category is 8 respondents $(10.25 \%)$. Whereas upon receiving the socialization, the knowledge level improved where number of respondent in good knowledge category is 69 respondents $(88.46 \%)$, fair knowledge category is 9 respondents $(11.53 \%)$, in other words respondent with less knowledge category is none.
\end{abstract}

Keywords: Sexually transmitted diseases, students, SMP

\section{INTRODUCTION}

Lack of information and knowledge of student's teenagers about prevention of sexually transmitted diseases can lead to increased cases of pe $\mathrm{n}$ yakit sexually transmitted among teens [4].

Negeri 1 Talawaan Middle School (SMP) is one of the schools located in the northern Minahasa Regency. Providing education or information about sex issues is still a little taboo and is reaping the pros and cons in the community in Talawaan Village, Dimembe District. Therefore, the information about the knowledge will be the prevention of sexually transmitted diseases in adolescents, is needed to improve the knowledge of students about the prevention of STDs so that students can prevent STDs early.

Efforts that must be made include the application of religious laws in the daily lives of parents and teachers becoming a model in everyday life, as well as providing information about reproductive health for students through counseling and through individualized guidance by teachers and counseling (BK) [3].

To increase knowledge through education about the prevention of sexually transmitted diseases and reproductive health in the early stages to students and schools to better provide important information related to local sexual health to students of SMP Negeri 1 Talawaan.

\section{METHOD}

The research design used was cross sectional. Population in this study are the students of SMP Negeri 1 Talawaan, grade 7 (Seven) and grade 8 (eight), amounting to 78 students. The instruments used were questionnaire (questionnaire), pre-test and post-test. Health education will be provided by counselling.

\section{RESULTS AND DISCUSSION}

Activities carried out for 3 days at the Junior High School I Talawaan $\mathrm{K}$ regencies of North Minahasa by providing health education to students of classes 7 and 8 that as many as 78 students about the prevention of sexually transmitted diseases and reproductive health add knowledge to the students about reproductive health in teenagers. Before counseling each student is given a questionnaire to measure the level of knowledge, the purpose of measuring the level of initial knowledge is to find out the success of the counseling given. After counseling is given again measured to find out whether 
there is an increase in knowledge from counseling or not. The results of counseling about sexually transmitted diseases and the dangers of transmission can be seen in the following

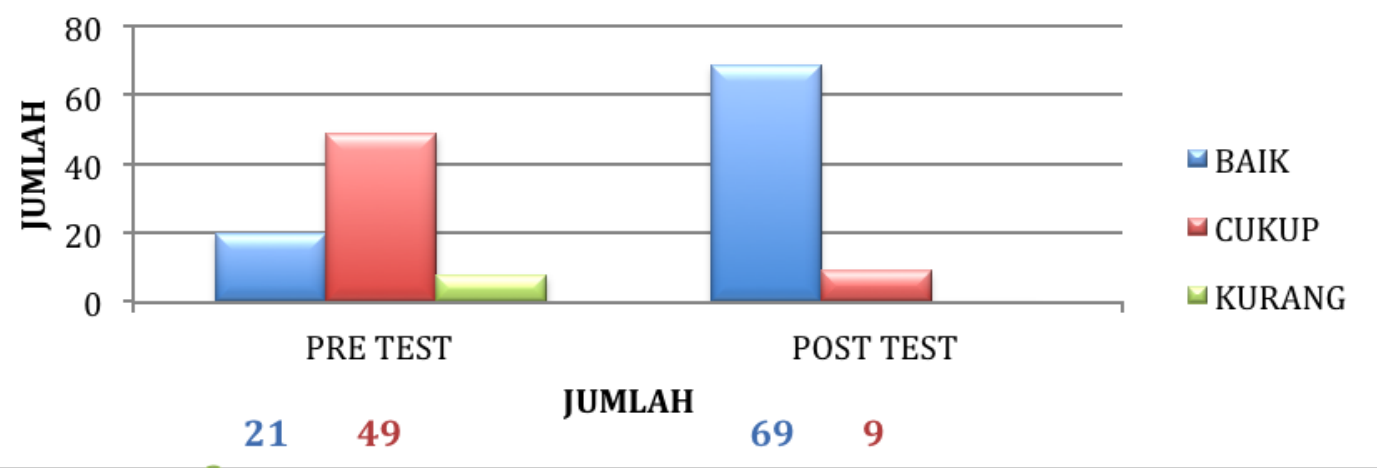

Figure 1. Level of Knowledge about the Prevention of Sexually Transmitted Diseases at SMP N 1 Talawaan

In figure 1 , it can be seen that the level of knowledge about the prevention of sexually transmitted diseases before being given counseling material with good knowledge categories is 21 respondents by $(26.92 \%)$, the knowledge category is quite as many as 49 respondents by $(62.82 \%)$, and knowledge categories are not as many as 8 respondents $(10.25 \%)$. Meanwhile, after receiving counseling material, there was an increase in the good knowledge category with 69 respondents $(88.46 \%)$ and the knowledge category was quite as many as 9 respondents $(11.53 \%)$ and for the less knowledge category it became nonexistent.

Based on the results of the test Pre TP about sexually transmitted diseases: Maximum Value $=8$ respondents who answer correctly, ann use values minimum $=70$ respondents who answer incorrectly

Based on the results of the TP Posttest about sexually transmitted diseases:

Note: Maximum Value $=9$ respondents answered correctly Minimum Value $=69$ respondents answered incorrectly The results of the community partnership program activities carried out were an increase in the knowledge of students of Talawaan I State Junior High School, Dimembe Subdistrict, North Minahasa Regency, regarding the prevention of sexually transmitted diseases and reproductive health. The output of the implementation of the community partnership program that is the results of the implementation of the activity will be published at the International seminar as poster poster.

\section{Situation Analysis}

\section{Geographical Conditions}

Sekolah Menengah Pertama (SMP) Negeri 1 Talawaan is located in North Minahasa Regency which is administratively part of the North Sulawesi Province. The location of SMP Negeri 1 Talawaan is geographically located between $04^{\circ} 40^{\prime}-05^{\circ} 40^{\prime} \mathrm{NL}$ and $126^{\circ} 20^{\prime}-127$ ${ }^{\circ} 00^{\prime}$ East. The distance from Manado to Village Talawaan District of Dimembe, using land transport and can be reached within 1 hour from Manado [1].

\section{DISCUSSION}

The work of the people living in Talawaan Village consists of farmers in general, followed by Civil Servants (PNS) and entrepreneurs. Infrastructure facilities in Melonguane Village consist of public facilities such as old law offices, places of worship, Puskesmas. Educational facilities in Talawaan Village are Elementary Schools, First High Schools. For junior high schools it is still in Dimembe subdistrict [1].

Social status of middle school children is adjusted to the work and income of each parent. Some students of SMPN 1 Talawaan have a moderate lifestyle, that is, students already have a personal communication tool in the form of a cellphone (cellphone). Thus students begin to get along and get in touch with people through social media that can be accessed from their mobile phones. From there they will get more and more information what they want [5]. Education and knowledge have an important role for life in adolescence. In addition, this age group is prone to inaccurate information from irresponsible people. 
Information is influenced by what and who gives the information. Incorrect and insufficient information will make someone ask questions and even try before knowing the truth [6].

With this partnership activity, it is expected that the problems of the knowledge of 7 th grade and 8th grade students of SMP Negeri 1 Talawaan can be overcome through counseling about sexually transmitted diseases so that they can increase knowledge while changing the behavior and lifestyle of SMP Negeri I Talawaan for the better.

The program activities of the Community Partnership on sexually transmitted diseases and reproductive health need to be carried out in a sustainable manner to improve the knowledge and attitudes of groups of students and young people and the community at large.

\section{CONCLUSION}

The implementation of the Community Partnership program activities in the form of health education about sexually transmitted diseases and reproductive health among 7th and 8th grade students of SMP Negeri 1 Talawaan, Dimembe Subdistrict can increase students' knowledge about the importance of reproductive health to improve the health status of Talawaan Village students.

\section{ACKNOWLEDGMENT}

Research conducted is a community partnership program. The research team worked closely with the Sam Ratulangi University dedication and research institute and assisted by several lecturers and students in conducting discussions to increase knowledge about sexually transmitted diseases among adolescents, in this case students of SMP Negeri 1 Talawaan.

\section{REFERENCES}

[1] BPS. 2017. Kecamatan Talawaan dalam Angka 2017. Airmadidi: BPS Kabupaten Minahasa Utara

[2] Desi, M.N, dkk. 2018. Perilaku Seksual Berisiko pada Pedagang Bawang Merah di Kecamatan Wanasari Kabupaten Brebes. Jurnal Promosi Kesehatan Indonesia Vol. 13 / No. 1 / Januari 2018

[3] Meilan, N., dkk. 2018. Kesehatan Reproduksi Remaja: Implementasi PKPR dalam Teman Sebaya. Malang: Wineke Media

[4] Panjaitan, C.M, dkk. 2017. Gambaran Pengetahuan dan Sikap terhadap Infeksi Menular Seksual pada Remaja di SMA Frater Don Bosco Manado. Jurnal e-Clinic (eCl), Volume 5, Nomor 2, Juli-Desember 2017

[5] Suwuh, F, dkk. 2017. Hubungan Penggunaan Smartphone dengan Perilaku Seksual Remaja di SMA Negeri 2 Langowan Kecamatan Langowan Utara. EJournal Keperawatan (eKp), Volume 5, Nomor 2, November 2017

[6] Tata, S. 2012. Konsep Sistem Informasi. Yogyakarta: CV Andi Offset 